\title{
1000 years of climatic change in China: ice-core $\delta^{18} \mathrm{O}$ evidence
}

\author{
P. N. Lin, L. G. Thompson, M. E. Davis and E. Mosley-Thompson \\ Byrd Polar Research Center, The Ohio State Universily, Columbus, OH 4.3210, U.S.A.
}

\begin{abstract}
Since 1987, ice cores have been drilled from the Dunde and Guliva ice caps on the Tibetan Plateau, western China. Here, the oxygen isotopic $\delta^{13} \mathrm{O}$ records for the last 1000 years from both these cores are compiled and compared. Using surface temperature observations since the mid-1960s from meteorological stations on the plateau and $\delta^{18} \mathrm{O}$ measured on precipitation collected contemporaneously, the empirical relationship: $\delta^{18} \mathrm{O}=0.6 T_{s}-12$ is established. $\delta^{18} \mathrm{O}$ appears to serve as a reasonable proxy for regional surface temperatures and a reasonable basis for reconstructing 1000 a proxy temperature records from Dunde and Guliya. The reconstructed temperature histories for Dunde (on the eastern Tibetan Plateau) and Guliya (on the western Tibetan Plateau) show some centennial-scale similarities, but reveal quite different histories for higher-frequency variability over the last millennium. The ice-core $\delta^{18} \mathrm{O}$ histories from Dunde and Guliya are compared with a tree-ring index from western China and the dust-fall record from eastern China, but show no consistent relationship. The most prominent similarity between the reconstructed temperature histories for Dunde and Guliya is the marked warming of the last few decades. From the 1000 a perspective provided by these ice-core records. the recent warming on Dunde is unique in its strength and persistence; however, the warming on Guliya (inferred from ${ }^{18} \mathrm{O}$ enrichment) is more recent (since 1985) and not unprecedented. This recent warming over the Tibetan Plateau is evident in the limited meteorological records.
\end{abstract}

\section{INTRODUGTION}

In the last decade, ice cores have provided a variety of unique paleoclimatic histories. For an overview see Langway and Oeschger (1989) and White and others (1989). Most of these have centered on high-latitude ice cores such as those from Greenland (e.g. Dansgaard and others, 1969, 1982; Grootes and others, 1993), the Canadian Arctic Koerner and Fisher, 1990) and Antarctica Epstein and others, 1970; Lorius and others, 1979, 1985). To complement these polar histories and provide further constraints upon models of global climatic variations, ice-core histories from high-elevation ice caps in the subtropics and tropics have begun to emerge. The first such history was from the Quelccaya ice cap (13 56' S, $70^{\circ} 50^{\prime} \mathrm{W}$; $5670 \mathrm{~m}$ a.s.l.) in Peru (Thompson and others, 1985, 1986, 1988). More recently a record was obtained from the Dunde ice cap $\left(38^{\circ} 06^{\prime} \mathrm{N}, 96^{\circ} 24^{\prime} \mathrm{E}\right.$; 5325 ma.s.l.; Fig. 1) in China (Thompson and others, 1989; Thompson, 1992).

Eastern China is rich in historical and documentary sources of climate information for the last millennium. Most of the Chinese paleoclimatic reconstructions are from regions east of $110^{\circ} \mathrm{E}$ and focus upon conditions during winter, although limited summer histories are emerging (Bradley and others, 1987). In western China, proxy histories (tree rings, ice cores) are severely limited, and their verification is hampered by the short and sparse

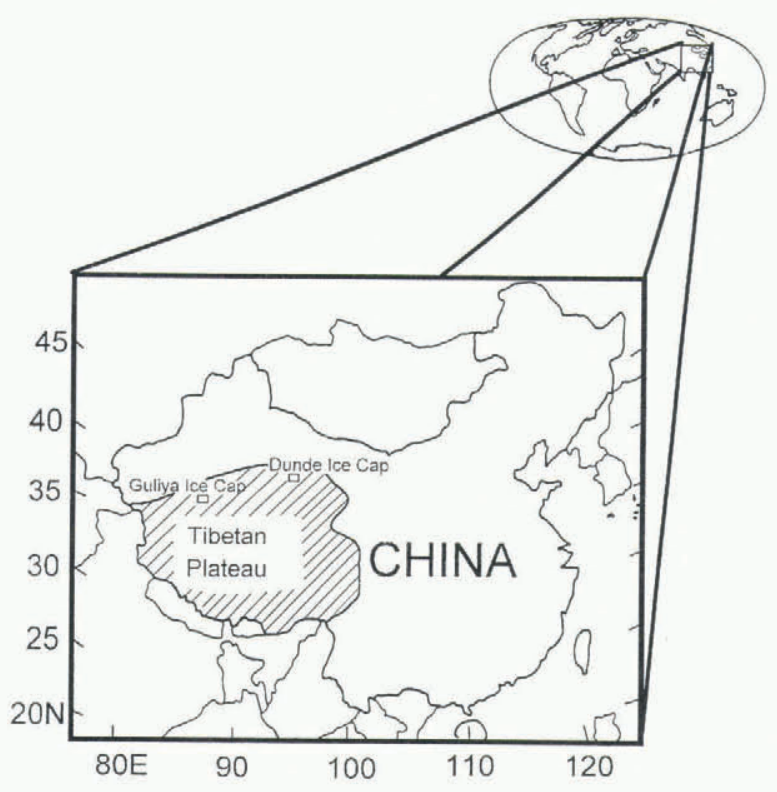

Fig. 1. Map showing the location of Dunde and Guliya ice caps, China.

meteorological records Bradley and Jones, 1993).

Nevertheless, the climate history of western China, particularly on the Tibetan Plateau, is an important component for reconstructing and understanding the 
Earth's climate history. The Tibetan Plateau, with an average elevation of $\approx 4500 \mathrm{~m}$, is one of the Earth's most imposing geomorphic features and affects the large-scale atmospheric circulation in the Northern Hemisphere (Reiter and Ding, 1980, 1981). The extensive summer heating of the plateau establishes and maintains the Asian summer monsoon circulation (Reiter and Gao, 1982). Thus, studies of the climate regime of the Tibetan Plateau have flourished and the potential for histories from western China has sparked the interest of the paleoclimatic community.

Since 1987, ice-core paleoclimate records have been emerging from two ice caps on the plateau: the Dunde ice cap on the northeastern side, and more recently the Guliya ice cap $\left(35^{\circ} 17^{\prime} \mathrm{N}, 81^{\circ} 29^{\prime} \mathrm{E}\right.$; $6710 \mathrm{ma}$ a.s.l.) on the northwestern side (Fig. 1) where a glaciological program was conducted from 1990 to 1992. In 1990 one pit was sampled and two cores were drilled: an $8 \mathrm{~m}$ core (C-1) and a $12 \mathrm{~m}$ core (C-2). In 1991 one pit was sampled and two cores were drilled: a $30 \mathrm{~m}$ core (C-1) and a $16 \mathrm{~m}$ core at the summit core (SC-1). In 1992 two deeper ice cores were recovered: a shorter core $(\mathrm{C}-1 ; 92.3 \mathrm{~m})$ at site 1 extended to an unconformity (see Thompson and others, 1995 ) t the longer core (C-2; $308.6 \mathrm{~m}$ ) reached bedrock at site 2. These cores are being analyzed for insoluble particulate concentrations and size distributions, anion $\left(\mathrm{SO}_{4}{ }^{2}, \mathrm{NO}_{3}, \mathrm{Cl}^{-}\right)$concentrations, and $\delta^{18} \mathrm{O}$. This paper focuses upon the similarities and differences of the Dunde and Guliya $\delta^{18} \mathrm{O}$ records for the last $1000 \mathrm{a}$ and compares these proxy histories with the limited data from western China and the more abundant climate histories from eastern and southern China.

\section{DISCUSSION}

Figure 2 demonstrates the reproducibility of the $\delta^{18} \mathrm{O}$ records in cores drilled at the same location on Guliya in three consecutive years (1990 92). The 1991 core was returned frozen while the 1990 and 1992 cores were cut, melted and bottled for return shipment. The first constraint upon the paleoclimatic utility of $\delta^{18} \mathrm{O}$ is the degree to which it reflects near-surface air temperature. To explore this, $\delta^{18} \mathrm{O}$ was measured on precipitation samples collected at the Delingha meteorological station south of the Dunde ice cap, and these were compared with contemporaneous air temperatures also measured at Delingha (Yao and Thompson, 1992). The empirical relationship between $\delta^{18} \mathrm{O}$ and air temperature (Fig. 3a) derived from these data is given by

$$
\delta^{18} O=0.6 T_{\mathrm{s}}-12
$$

where $T_{\mathrm{s}}$ is air temperature. The $\delta^{18} \mathrm{O}$-temperature coefficient of 0.6 is identical to that established for the longer records from other mid- and high-latitude regions (e.g. Rozanski and others (1992) report a value of 0.6). To test further how well $\delta^{18} \mathrm{O}$ reflects air temperatures, the annual averages of $\delta^{18} \mathrm{O}$ for the three cores from site 1 on Guliya (Fig. 2) are compared (Fig. 3b) with mean annual air temperatures from Mangnai meteorological station $\left(38.2^{\circ} \mathrm{N}, 90.1^{\circ} \mathrm{E} ; 3139 \mathrm{~m}\right.$ a.s.l. $)$. The agreement between mean annual $\delta^{18} \mathrm{O}$ and air temperatures is quite

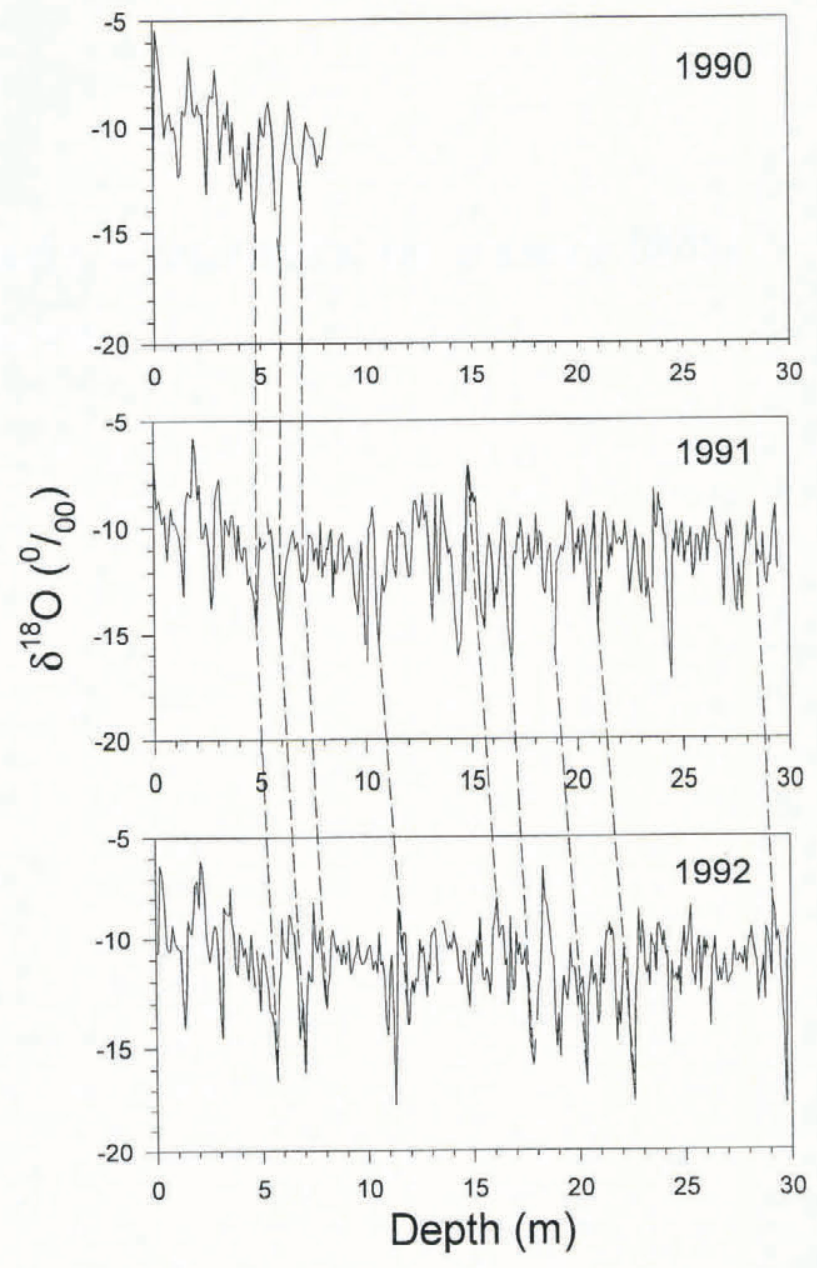

Fig. 2. The continuous isotopic profiles for three cores drilled in successive years (1990 92) at the same site on the Guliya ice cap. The dashed lines indicale correlative features.

good considering the distance and elevation differences and other environmental factors which may affect $\delta^{18} \mathrm{O}$. A marked warming trend since 1985 is evident in both the ice-core records and the station observations. It is clear that $\delta^{18} \mathrm{O}$ of the snow falling on Guliya provides a reasonable proxy for the near-surface air temperature.

The time-scales for the upper $380 \mathrm{a}$ of the Guliya and Dunde cores were established by counting the visible dust lavers deposited annually. This allows the annual averages of dust content and $\delta^{18} \mathrm{O}$ to be calculated. For the older part of the Dunde cores the time-scale is a model-based time-depth relationship for the combination of cores 1 and 3 in which similar features were considered coeval. Since it was impossible to count annual dust layers down to the bottom of both Dunde cores, the final timescale is based on the flow-model approach. In contrast, the dating for the last 1000 years from the Guliya core- 2 is based on counting visible dust layers (see Thompson and others (1995) for Guliya time-scale discussion).

Figure $4 \mathrm{a}$ and $\mathrm{b}$ illustrate the $1000 \mathrm{a} \delta^{18} \mathrm{O}$ record from Guliya core-2 and the combined histories from the Dunde deep cores (1 and 3). A surprising result is the marked difference in the $\delta^{18} \mathrm{O}$ histories from these two ice caps. The difference in mean values (Dunde: $-10.88 \%$; Guliya: $-14.77 \%$ ) is expected and consistent with the different elevations of the drill sites (Dunde: $5325 \mathrm{~m}$ a.s.l.; Guliya: 

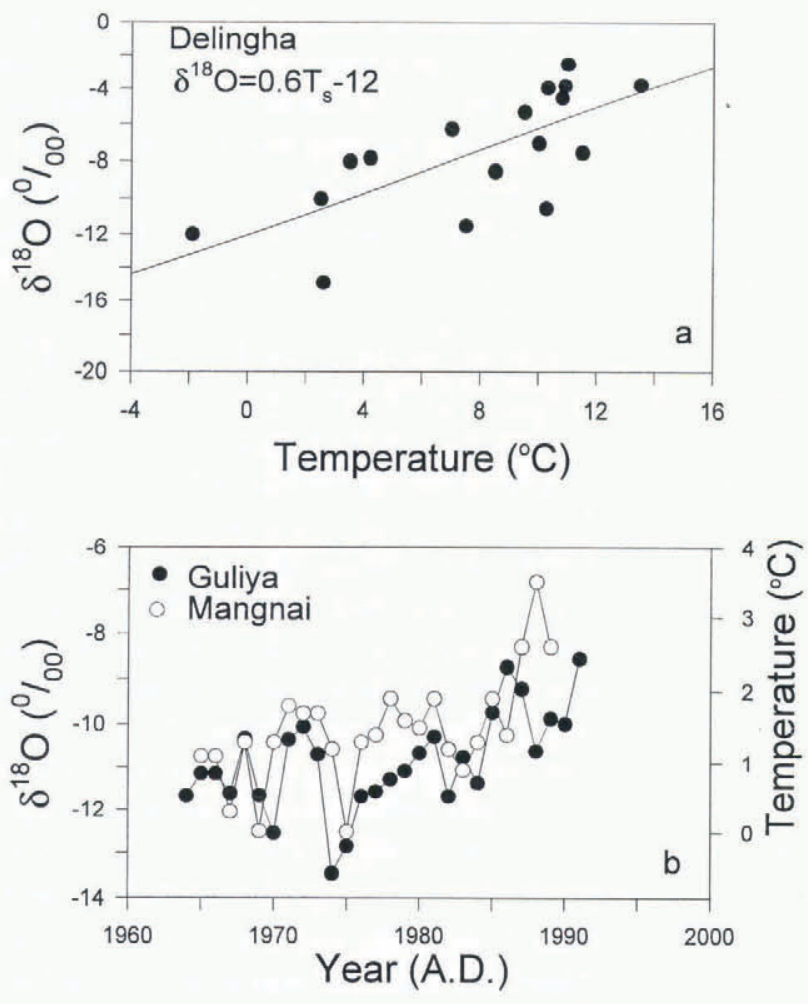

Fig. 3. a. Mean annual air temperatures from the Delingha meteorological station (Yao and Thompson, 1992 ) are plotted against the mean annual $\delta^{18} \mathrm{O}$ data from contemporaneous precipitation samples. b. Mean annual temperatures from Mangnai meteorological station are plotted against the mean annual $\delta^{18} O$ data from the Guliya ice cap.

$6200 \mathrm{~m}$ a.s.l.). However, the major warm and cool periods (isotopically inferred) are highlighted using a 50 a running mean (Fig. 4; dark curves) and clearly reveal a period from 1250 to 1500 when warming on Guliya was contemporaneous with cooling on Dunde. In fact, comparison of the 50 a running means suggests that the temperature regimes (inferred from $\delta^{18} \mathrm{O}$ ) on these two ice caps are dissimilar at times and often in anti-phase. Although some modest time-scale inaccuracies are possible, these are unlikely to account for the differences in the $\delta^{18} \mathrm{O}$ patterns in the Dunde and Guliya ice cores.

The two ice caps are situated $1400 \mathrm{~km}$ apart on opposite sides of the Tibetan Plateau under the influence of somewhat different climatic regimes. Dunde lies on the northeastern margin of the plateau while Guliya is on the northwestern side. Thus, it is not surprising that their $\delta^{18} \mathrm{O}$ histories appear different, particularly since moisture sources vary over the plateau (Luo and Yanai, 1983, 1984). Observations of contemporary climate regimes on the plateau Qian and others, 1988) reveal such spatial differences. Most of the moisture for the eastern side of the plateau, where Dunde is located, is associated with the highly convective Indian monsoonal rains from southwestern China (Luo and Yanai, 1983). Here the release of latent heat associated with cumulus-convective precipitation contributes to atmospheric heating (Tao and Ding, 1981; Yeh, 1981; Luo and Yanai, 1984). On the western side of the plateau, heating is largely from vertical convection driven by surface heating. The prevailing
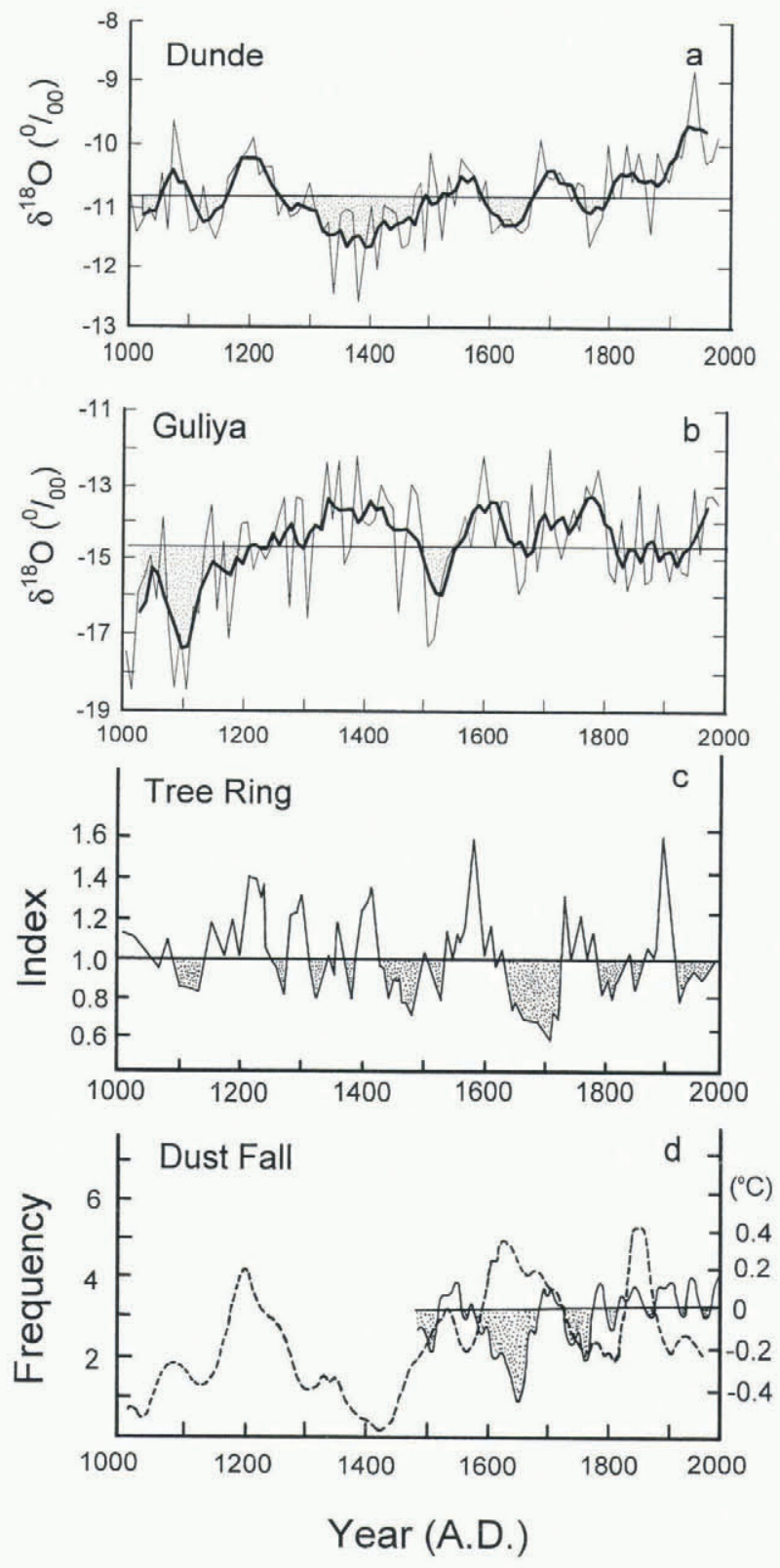

Fig. 4. The decadal average $\delta^{18} O$ from a. the Dunde ice cap and b. the Guliya ice cap are shown for the last $1000 a$. The darker solid line indicates the 50 a running mean. $c$. Tree-ring widths from four juniper trees provide a proxy for climate in the Qilian Shan of north-central China (after Wang and others, 1983). d. Dust-fall frequency has been recorded in central and eastern China. The dashed line represents the 50 a running mean (after Zhang, 1984), and the solid line indicates lemperalure fluctuations (Chu, 1973).

moisture source for the Guliya ice cap, on the western side of the plateau, is the Arabian Sea Ohata and others, 1989). On Guliya the annual precipitation is lower, averaging $\approx 180 \mathrm{~mm}$ w.e. (Thompson and others, 1995), compared to $400 \mathrm{~mm}$ w.e. on Dunde (Thompson and others, 1990; Thompson, 1992).

Other factors affecting the preserved $\delta^{18} \mathrm{O}$ history include: localized snow drifting; the addition of locally derived moisture from nearby convective activity due to intense radiational heating of the surrounding area; loss of mass by ablation; and differing accumulation rates. 
Figure 2 illustrates that the three ice cores from Guliya show consistent isotopic patterns, suggesting that, at the same site at least, the effect of these localized factors is minor. The potential contribution of these factors to differences on Guliya and Dunde is difficult to assess.

\section{COMPARISON WITH OTHER DATA}

Proxy histories are necessarily imperfect representations of their surroundings because they are limited by the robustness of their time-scale, their spatial representativeness and the physical interpretation of the proxy itself. One of the few proxy records available from western China is a 935 a record of tree-ring widths in four juniper trees covering the upper and lower limits of the forest zone in the Qilian Shan region (Wang and others, 1983). Thinner rings are interpreted as reflecting sub-optimal growing conditions which could be cooler temperatures, reduced precipitation or some combination. Wang and others (1983) interpreted thin ring widths as reflective of cooler temperatures, and noted three prominent and/or prolonged cool periods and one less extensive event (Fig. $4 \mathrm{c}$. Cooler conditions lasting about $70 \mathrm{a}$ are centered on 1480, 1690 and 1810 while a shorter cool phase appears much earlier in the record, around 1120. Wang and others (1983) suggested that the three cold periods of the Ming-Qing dynasty (1428-1865) correspond to the socalled "Little Ice Age" in Europe, with the main cold period at 1725 .

The major occurrences of thinner tree rings appear to be associated qualitatively with more negative (cooler) $\delta^{18} \mathrm{O}$ intervals on Guliya, but show little correspondence to the Dunde $\delta^{18} \mathrm{O}$ record. This is interesting as the junipers are from $\approx 3000 \mathrm{~m}$ in the Qilian Shan where the Dunde ice cap is located. Also note from the earlier discussion that the $\delta^{18} \mathrm{O}$ histories from Dunde and Guliya are dissimilar at times, with some longer-term cooler and warmer intervals out of phase.

Two of the three "Ming Qing-dynasty" cool phases (inferred from limited tree-ring data) appear in the $\delta^{18} \mathrm{O}$ history from Guliya which also suggests a persistence of cooler conditions from 1800 to the mid-1900s. Interestingly, the most prolonged cooling in the Guliya $\delta^{18} \mathrm{O}$ history is from about 1050 to 1200 , contemporaneous with the marked yet brief decline in ring widths. It should be noted that this early part of the tree-ring record is based upon two trees, which highlights the spatial limitation of the data. In fact, the tree-ring thicknesses appear to be more reflective of the net accumulation histories on the two ice caps (see Thompson and others, 1995, figs 7 and 8 ), but still with a stronger resemblance to the Guliya history. Previous investigations of tree-ring records from lower-elevation $(<3500 \mathrm{~m}$ ) sites in Tibet (Wu, 1992) have indicated that ring widths in this dry region are more reflective of precipitation variations than of temperature variations. The ice-core data would tend to support this idea.

Figure 4d presents a history of the frequency of dust fall (dashed line) for an area from Xinjiang to the east coast of China and from Nei Mongol to the south of the Yangtze River (Zhang, 1984), an area consistent with the loess distribution in China (Liu and others, 1981).
Inferred (proxy) temperatures since 1500 (solid line: after Chu, 1973) led Zhang to suggest that cooler periods were associated with more dusty atmospheric conditions, while dust flux appears diminished when conditions are warmer. The transportation of dust from northwest to southeast China is related mainly to variations in atmospheric circulation over mainland China. In winter, the strong Siberian high moves southward, leading the polar frontal zone south as well. This enhances the stronger winter monsoon and favors the entrainment and transport of dust during cold periods (Zhang, 1984). The dust is entrained within the Mongolian cyclone, is transported eastward by the upper-level westerlies and slowly settles out over the eastern half of China. In addition, most of the periods of high dust deposition appear to be associated with conditions of lower humidity, indicating that dust storms are associated with the dry season (Zhang, 1984).

The dust history (Fig. 4d) from eastern China shows no consistent relationship with the Dunde and Guliya $\delta^{18} \mathrm{O}$ records over the last $1000 \mathrm{a}$. The low frequency of dust storms from 1300 to $1450 \mathrm{AD}$ is correlative with isotopically warmer conditions on Guliya and cooler conditions on Dunde. As with the temperature comparisons discussed above, the eastern China dust history appears more consistent with the net accumulation histories from Guliya and Dunde (Thompson and others, 1995, figs 7 and 8). The period of elevated dust (eastern China) from 1150 to $1300 \mathrm{AD}$ is associated with reduced accumulation on Guliya after which the frequency of dust storms in the east drops as accumulation on Guliya increases. In the more recent (better documented and dated) part of these records the peak in dust flux in about $1850 \mathrm{AD}$ is correlative with a period of substantially lower net accumulation on both Guliya and Dunde. Likewise, the reduction in dust-storm frequency since the turn of the 19th century is associated with well above average net accumulation on both ice caps.

These records suggest a very complex relationship between the temperature and precipitation over the plateau and the temperature and atmospheric dustiness over the eastern half of China. This preliminary investigation suggests that net accumulation on the ice caps, rather than temperature, appears more closely related to atmospheric conditions (temperature and dustiness) in the eastern half of China where proxy and historical climate observations are more abundant. Also, for the earlier part of the record (prior to $1500 \mathrm{AD}$ ) the lack of observations (e.g. tree rings, dust fall) and their imprecise time-scales make comparison with the ice-core histories tentative at best. It is necessary to stress as well that $70-80 \%$ of precipitation on the ice caps falls during the summer monsoon season so that the $\delta^{18} \mathrm{O}$ history probably reflects summer conditions more strongly than annually averaged conditions, and that at these high elevations there is a potential for sublimation $\left({ }^{18} \mathrm{O}\right.$ enrichment) during the dry part of the year. Thus, $\delta^{18} \mathrm{O}$ measurements are predestined to be imperfect representations of near-surface air temperatures. Much of the dust deposition on the ice caps (and over eastern China as well) is associated with the dry winter monsoon season so that dust flux is likely to be more representative of atmospheric conditions in winter than of annually averaged conditions. 
The more recent part of the ice-core $\delta^{18} \mathrm{O}$ records is compared with surface temperature observations in Figure 5. The 5 a running mean of the annual $\delta^{18} \mathrm{O}$ values from 1850 to 1992 from Guliya and Dunde (both dated to 1850 by layer counting) is shown in Figure 5a and b. As noted earlier, isotopically warm and cold periods are not synchronous for Dunde and Guliya, and this is particularly true for annual and decadal-scale data. However, both records reveal a persistence of higher $\delta^{18} \mathrm{O}$ values (warmer temperatures) since the 1940 s, similar to the warming in the Northern Hemisphere land-surface temperatures since the 1920s (Fig. 5c) and the Indian Ocean surface temperatures (Fig. $5 \mathrm{~d}$ ). The $\delta^{18} \mathrm{O}$ data from Guliya and Dunde also correspond reasonably well with the temperature record from the Indian Ocean (Briffa and Jones, 1993), which is encouraging as the precipitation reaching the western part of the Tibetan Plateau originates primarily over the Indian Ocean during the summer monsoon season Luo and Yanai, 1983, 1984).
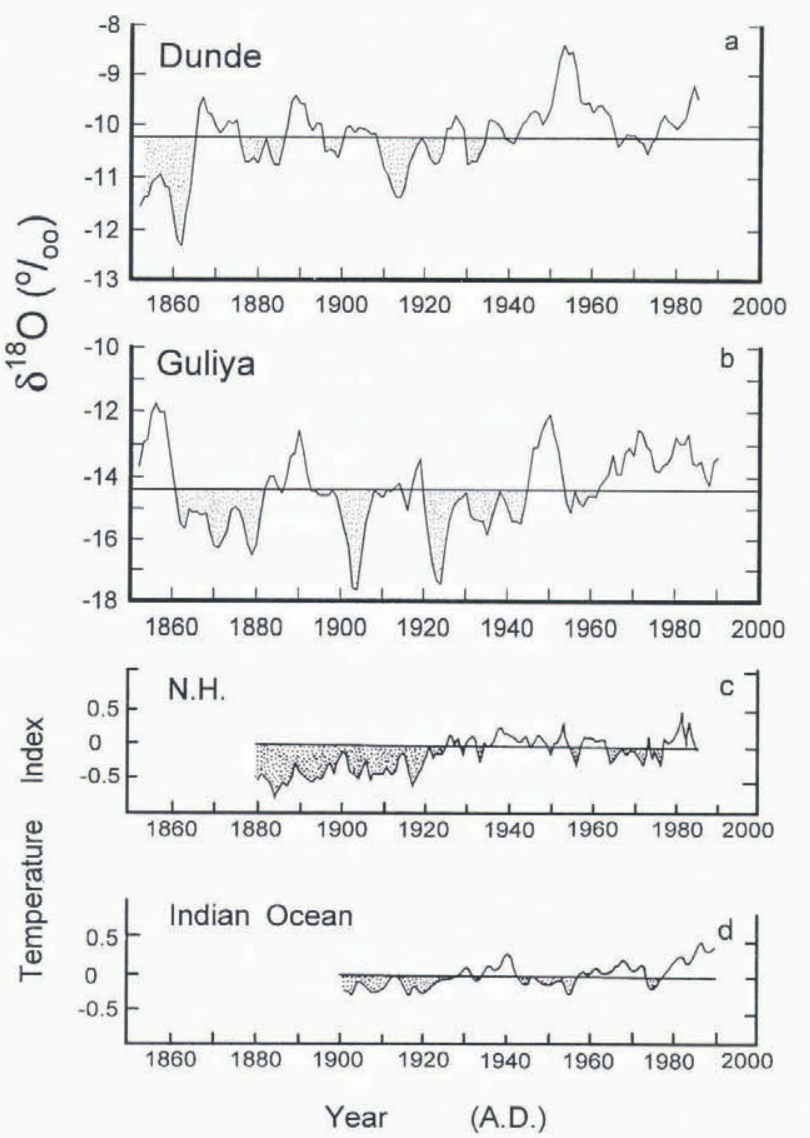

Fig. 5. The 5 a running mean of $\delta^{18} \mathrm{O}$ from 1850 to 1992 from $a$. Dunde and b. Guliya ice caps is compared with two other temperature histories: c. Northern Hemisphere temperature variations (Hansen and Lebedeff, 1987) and d. Indian Ocean surface temperature data (Briffa and fones, 1993).

Longer temperature histories are available from southern and eastern China. Here "Mei Yu" or plum rains are a main source of precipitation, dominant in spring and summer, over most of China south of the
Yangtze River. Summer air temperatures from southeastern China (Fig. 6b) and from the lower Yangtze River (Fig. 6c) have been reconstructed for the last five centuries. The coldest period, the mid-17th century (around $1650 \mathrm{AD}$ ), is prominent in all records. The normalized mean summer temperatures (Fig. 6d) and the normalized mean winter temperatures (Fig. 6e) also indicate cooler conditions around $1850 \mathrm{AD}$. Note that the $\delta^{18} \mathrm{O}$ records in Figure 6 are shown with respect to their (1860-1959) means for consistency with the other data (Fig. 6b-e). The Dunde $\delta^{18} \mathrm{O}$ history is much more similar to the temperature history in southeastern China than is the Guliya $\delta^{18} \mathrm{O}$ history. The most prominent climate event in all the records $\left(\delta^{18} \mathrm{O}\right.$, tree ring, dust fall is the cool period around $1650 \mathrm{AD}$ which appears to have affected both eastern and western China. Another

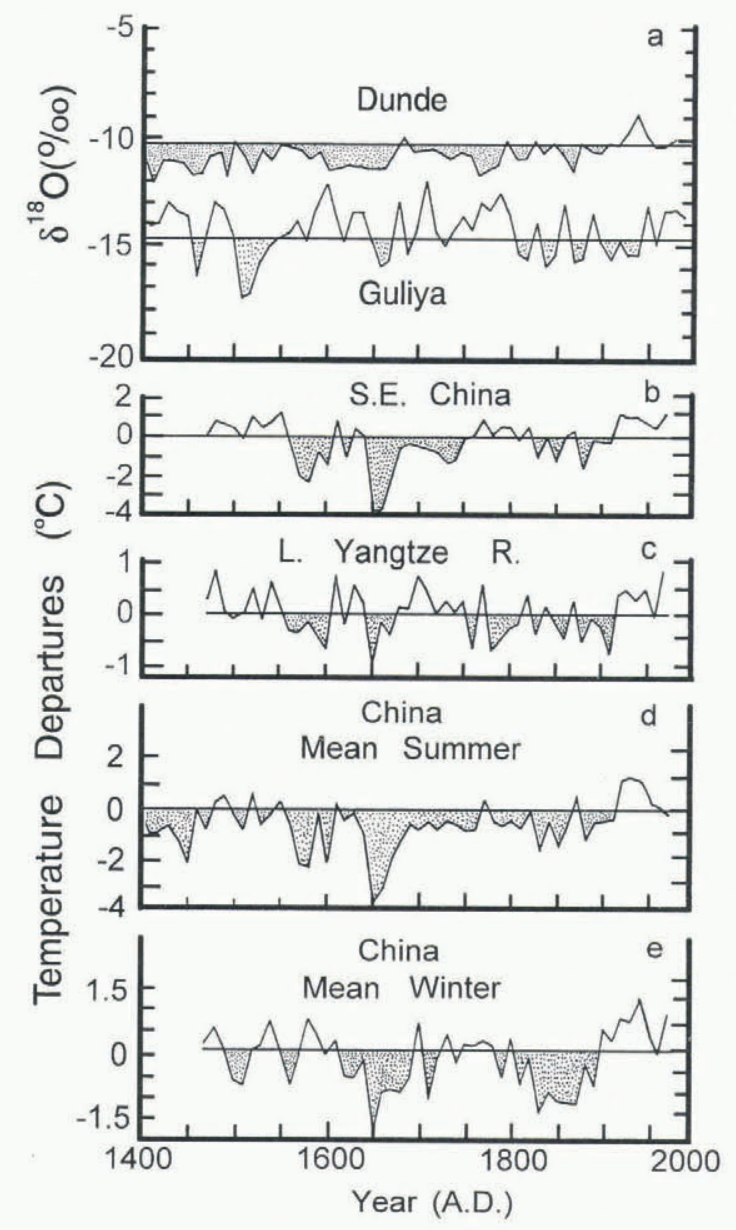

Fig. 6. Decadal averages of $\delta^{18} O$ from $a$. Dunde and Guliya are compared with available temperature records from other areas of China. All data are shown relative to their respective 1860 1959 means. b. Summer temperalure variations in southeast China are from Wang and others (1991). c. Summer lemperature anomalies for the Lower langtze River are from Wang and Wang (umpublished information, 1992) and Bradley and fones (1993). d. Mean normalized summer temperatures for eastern China are from Wang and Wang (1990); Wang (1991); and Wang and others (1991). e. Mean normalized winter temperatures for eastern China are from Zhang and Gong (1979); Zhang (1980); Wang and Wang (1990); Wang (1991); and Wang and others (1991). 
important feature in 1000 a $\delta^{18} \mathrm{O}$ records from Dunde and Guliya is a warming trend in the 20th century. Although not as prominent in the decadally averaged data from Guliya, since 1985 it is unambiguously an "isotopically" warm feature in both summer and winter (i.e. the highest and lowest $\delta^{18} \mathrm{O}$ values) for all three cores (Fig. 2).

\section{CONGLUSIONS}

The 1000 a $\delta^{18} \mathrm{O}$ records from the Dunde and Guliya ice caps on the Tibetan Plateau, western China, display different climatic variations which may reflect their different moisture sources. Altitude differences only affect $\delta^{18} \mathrm{O}$ mean values, and dating errors are unlikely to contribute strongly to the observed differences. The $\delta^{18} \mathrm{O}$ measurements of snow collected on Guliya reflect airtemperature trends at Mangnai meteorological station, suggesting that $\delta^{18} \mathrm{O}$ of the snow falling on Guliya provides a reasonable proxy for the near-surface air temperature.

The ice-core $\delta^{18} \mathrm{O}$ histories from Dunde and Guliya are compared with a tree-ring index from western China and the dust-fall record from eastern China, but show no consistent relationship. Interestingly, the net accumulation histories from Dunde and Guliya appear to be more consistently related to each other and with dust fall in eastern China. Large-scale trends in the $\delta^{18} \mathrm{O}$ history from Dunde are more similar to those in eastern China than are the trends from the Guliya ice cap far to the west. Both ice-core histories and the other limited proxy records suggest a widespread cool period around $1650 \mathrm{AD}$. The Guliya history contains a major cool phase around $1500 \mathrm{AD}$, but this does not appear to have extended to the east. Finally, a most important observation is the recent warming reflected in the records from both ice caps. The warming appears to have begun several decades earlier on the lower-elevation Dunde ice cap and more recently, since 1985, on the higher Guliya ice cap to the west. The older parts of the Guliya core are currently being analyzed and along with the contemporaneous history from Dunde should provide a proxy record, particularly as transfer functions between $\delta^{18} \mathrm{O}$ and temperature and the relationship between temperature and precipitation are better established.

\section{ACKNOWLEDGEMENTS}

This research was supported by the U.S. National Science Foundation's Office of Climate Dynamics and the Division of Polar Programs (ATM-8519794, ATM89116635, DPP-9014931), the National Geographical Society (3323-86, 4309-90 and 4522-91), The Ohio State University and the Natural Science Foundation of China. We thank researchers at the Lanzhou Institute of Glaciology and Geocryology for their efforts. We acknowledge the supreme efforts of all those participating in the field program. Comments by M. Nakawo and two anonymous reviewers substantially improved the manuscript and are sincerely appreciated. This is contribution No. 923 of Byrd Polar Research Center, The Ohio State University.

\section{REFERENCES}

Bradley, R.S. and P.D. Jones. 1993. "Little Ice Age" summer temperature variations: their nature and relevance to recent global warming trends. Holocene, 3 4), 367-376.

Bradley, R.S., H. F. Diaz, P. D. Jones and P. M. Kelly. 1987. Secular fluctuations of temperature over Northern Hemisphere land areas and mainland China since the mid-19th century. In Ye, D.H., C.B. Fu. J.P. Chao and M. Yoshino, eds. The climate of China and global climate. Berlin, Springer-Verlag, 76-87.

Briffa, K. R. and P.D. Jones. 1993. Global surface air temperature variations during the twentieth century: Part 2. Implications for largescale high-frequency palaeoclimatic studies. Holocene, 3 1), 77-88.

Chu, K. 1973. A preliminary study on the climate fluctuations during the last 5000 years in China. Sci. Sin., 16 2), 168-189.

Dansgaard, W., S.J. Johnsen, J. Moller and C. C. Langway, Jr. 1969. One thousand centuries of climatic record from Camp Century on the Greenland ice sheet. Science, 166 (3903), 377-381.

Dansgaard, W. and 6 others. 1982. A new Greenland deep ice core. Science, $218(4579), 1273-1277$.

Epstein, S., R. P. Sharp and A.J. Gow. 1970. Antarctic ice sheet: stable isotope analyses of Byrd Station cores and interhemispheric climatic implications. Science, 168 (3939), 1570-1572.

Grootes, P. M., M. Stuiver, J. W. C. White, S. Johnsen and J. Jouzel. 1993. Comparison of oxygen isotope records from the GISP2 and GRIP Greenland ice cores. Nalure, $\mathbf{3 6 6} 6455), 552554$.

Hansen, J. and S. Lebedeff. 1987. Global trends of measured surface air temperature. J. Geophys. Res,, 92 (D11), 13,345-13,372.

Koerner, R. M. and D. A. Fisher. 1990. A record of Holocene summer climate from a Canadian high-Arctic ice core. Nature, 343 6259), $630-631$.

Langway, C. C., Jr and H. Oeschger. 1989. Introduction. In Oeschger, $\mathrm{H}$. and C. C. Langway, Jr, eds. The environmental record in glaciers and ice sheets. Chichester, etc., John Wiley and Sons, 1-11.

Liu, T.S., X.F. Gu., Z.S. An and Y.X. Fan. 1981. The dust fall in Beijing, China on April 18, 1980. Geol. Soc. Am. Spec. Pap. 186, 149-157.

Lorius, C., L. Merlivat, J. Jouzel and M. Pourchet. 1979. A 30,000-yr isotope climatic record from Antarctic ice. Nature, 280 (5724), 644648.

Lorius, C. and 6 others, 1985. A 150,000-year climatic record from Antarctic ice. Nalure, 316 (6029), $591-596$.

Luo, H. and M. Yanai. 1983. The large-scale circulation and heat sources over the Tibetan Plateau and surrounding areas during the early summer of 1979. Part I: Precipitation and kinematic analysis. Mon. Weather Rev., 111, 922944.

Luo, H. and M. Yanai. 1984. The large-scale circulation and heat sources over the Tibetan Plateau and surrounding areas during the early summer of 1979. Part II: Heat and moisture budgets. Mon. Weather Rev., 112, $966-989$.

Ohata, T., S. Takahashi and X. Kang. 1989. Meteorological conditions of the west Kunlun mountains in the summer of 1987. Bull. Glacier Res., 7, 67-76.

Qian, Y., H. Yian, Q. Wang and A. Wang. 1988. Numerical studies of topography effect on planetary atmosphere. In Science Express. [In Chinese.]

Reiter, E. R. and Y.H. Ding. 1980. The role of the Qinghai-Xizang Plateau in feedback mechanisms affecting the planetary circulation. Scientia Atmospherica Sinica, 4(4), 301-309.

Reiter, E. R. and Y.H. Ding, 1981. The role of the Qinghai Xizang Plateau in feedback mechanisms affecting the planetary circulation. Scientia Atmospherica Sinica, 5 1), 9-22.

Reiter, E. R. and D. Y. Gao. 1982. Heating of the Tibetan Plateau and movements of the south Asian high during spring. Mon. Weather Rev., 110, $1694-1711$.

Rozanski, K., L. Araguas-Araguas and R. Gonfiantini. 1992. Relation between long-term trends of oxygen-18 isotope composition of precipitation and climate. Science, 248, 981-985.

Tao, S. Y. and Y. H. Ding. 1981. Observational evidence of the influence of the Qinghai-Xizang (Tibet) Plateau on the occurrence of heavy rain and severe convective storms in China. Bull. Am. Meteorol. Soc., 62. $23-30$.

Thompson, L.G. 1992. Ice core evidence from Peru and China. In Bradley, R.S. and P. D. Jones, eds. Climate since A.D. 1.500. London, Routledge, 517-548.

Thompson, L. G., E. Mosley-Thompson, J. F. Bolzan and B. R. Koci. 1985. A 1500-year record of tropical precipitation in ice cores from the Quelccaya ice cap, Peru. Science, 229 (4717), 971-973.

Thompson, L. G., E. Mosley-Thompson, W. Dansgaard and P.M. Grootes, 1986. The Little Ice Age as recorded in the stratigraphy of 
the tropical Quelccaya ice cap. Science, 234(4774), 361-364.

Thompson, L. G., M. E. Davis, E. Mosley-Thompson and K-b. Liu. 1988. Pre-Incan agricultural activity recorded in dust layers in two tropical ice cores. Nalure, 336 6201), 763-765.

Thompson. L. G. and 9 others. 1989. Holocene-Late Pleistocene climatic ice core records from Qinghai-Tibetan Plateau. Science, 246 4929), 474477.

Thompson, L. G. and 9 others. 1990. Glacial stage ice-core records from the subtropical Dunde ice core. Ann. Glaciol., 14, $288-297$.

Thompson, L. G. and 6 others. 1995. A 1000 year climatic ice-core record from the Guliya ice cap, China: its relationship to global climate variability. Ann. Glaciol., 21 (see paper in this volume).

Wang, R., S. Wang and K. Fraedrich. 1991. An approach to reconstruction of temperature on a seasonal basis using historical documents from China. International Journal of Climatolog), 11, 381-392.

Wang, S. 1991. Reconstruction of palaeo-temperature series in China from the 1380s to the 1980s. Wiurzb. Geogr. Arb.. 80, 1-19.

Wang, S. and R. Wang, 1990. Seasonal and annual temperature variations since 1470 A.D. in east China. Acta Meleorol. Simica, 4 4), $428-439$.

Wang, Y.X., G.Y. Liu, X.G. Hang and C.F. Li. 1983. The relationships between tree rings of Qilianshan juniper and climatic change and glacial activity during the past 1000 years in China. Liexue Tongbao, 28 12) 1647-1652.

White. J. W. C. and 11 others. 1989. Group report: How do glaciers record environmental processes and preserve information? In Oeschger. H. and C. C. Langway, Jr, eds. The environmental record in glaciers and ice sheets. Chichester, etc. John Wiley and Sons, 8598.

Wu, X. D. 1992. Dendroclimatic studies in China. In Bradley, R. S. and P. D. Jones, eds. Climate since A.D. 1500. London, Routledge, $432-445$.

Yao, T. and L. G. Thompson. 1992. Trends and features of climatic changes in the past 5000 years recorded by the Dunde ice core. $A \mathrm{~m}$. Glaciol.. 16. $21-24$.

Yeh. T. C. 1981. Some characteristics of the summer circulation over the Qinghai Xizang (Tibet) Plateau and its neighborhood. Bull. Am. Meteorol. Soc., 62, $14-19$.

Zhang, D. 1980. Winter temperature changes during the last 500 years in south China, Kexue Tongbao, 25 6), 597.

Zhang. D. 1984. Synoptic-climatic studies of dust fall in China since historic times. Sci. Sin., 278 8. 825836.

7.hang, D. and G. Gong. 1979. Some characteristics of climatic fluctuations in China since 16th century. Acta Geogr. Sinica, 34. 238. 